\title{
KRITERIA NILAI PRODUK GAME EDUKASI MAHASISWA UNIVERSITAS DARMA PERSADA DENGAN METODE MAGIQ
}

\author{
Lies Sunarmintyastuti ${ }^{1}$, Dona Katarina ${ }^{2}$, Erlin Windia Ambarsari ${ }^{3}$, Dedin Fathudin ${ }^{4}$ \\ ${ }^{1,2,3}$ Universitas Indraprasta PGRI \\ Jl. Nangka Raya No.58 C, RT.5/RW.5, Tj. Bar., Jagakarsa, Kota Jakarta Selatan, Daerah Khusus Ibukota Jakarta 12530 \\ ${ }^{1}$ liesbina@yahoo.com \\ 2dona.katrin@gmail.com \\ 3erlinunindra@gmail.com \\ ${ }^{4}$ Universitas Pamulang \\ Jl. Surya Kencana No. 1, Pamulang Barat, Pamulang, Kota Tangerang Selatan, Banten 15417 \\ 4dosen00398@unpam.ac.id
}

\begin{abstract}
ABSTRAK
Perkembangan internet cukup pesat dan penggunaannya lebih banyak untuk mendistribusikan produk secara online, tanpa kecuali distribusi Game. Mahasiswa sendiri sebagai pengembang baru dapat pula berpartisipasi dalam pembuatan Game dan untuk bersaing ataupun disukai oleh pencinta Game dengan mempertimbangkan kebutuhan Gamer masa kini. Pembuatan Game yang paling mudah dibuat adalah Game Edukasi. Oleh karena itu, pada penelitian ini mengamati Game Software yang dibuat oleh Mahasiswa Universitas Darma Persada untuk melihat nilai produk berdasarkan fungsi secara relatif. Metode penelitian yang digunakan adalah deskriptif kuantitatif sedangkan teknik analisa yang digunakan adalah statistik deskriptif dengan menggunakan metode MAGIQ. Kekurangan pada Game Edukasi tersebut adalah belum memasukan kriteria Level dan Reward yang merupakan titik penting pada Gameplay. Karena itu perlu dilakukan pengujian alpha dalam pengembangan Game yang selanjutnya perlu dilakukan dengan meninjau berdasarkan standar kualitas ISO 9126.
\end{abstract}

Kata Kunci : Game Edukasi, Nilai Produk, MAGIQ

\section{A. PENDAHULUAN}

Perkembangan ilmu pengetahuan dan teknologi tidak pernah berhenti menghasilkan produk teknologi yang tidak terhitung jumlahnya. Salah satu terobosan besar upaya untuk mengembangkan fungsi dari teknologi adalah kemunculan internet. Pada saat ini internet tidak hanya digunakan untuk memenuhi kebutuhan informasi tetapi juga dipergunakan sebagai media penyebaran pemasaran produk, misalkan tokopedia, bukalapak, Zelora, Bhinneka dan lain sebagainya. Pesatnya aktivitas melalui online, menyebabkan distributor industry Game mengambil peluang tersebut untuk memudahkan pengguna dalam melakukan transaksi, khususnya para gamer. Selain itu, alasan distributor memanfaatkan peluang dikarenakan untuk menekankan terjadinya pembajakan Game Software dan melindungi hak cipta developer.

Perusahaan konsol dari Nintendo, Playstation ataupun Xbox mempunyai pasarnya sendiri, dimana Game yang dijual tergantung dengan kebutuhan konsol. Selain itu dengan maraknya pengguna Laptop, sudah tersedia Steam atau Emago, dan pengguna gawai dengan Playstore atau App Store. Akibatnya, banyak developer mengupload ke distributor tersebut baik secara perorangan maupun Startup Game.

Mahasiswa sendiri sebagai pengembang baru dapat pula berpartisipasi dalam pembuatan Game dan untuk bersaing ataupun disukai oleh pencinta Game dengan mempertimbangkan kebutuhan Gamer masa kini. Pembuatan Game yang paling mudah dibuat adalah Game Edukasi. Pemanfaatan dari Game Edukasi adalah merubah pola belajar agar tidak jenuh dan bosan (Fithri \& Setiawan, 2017), khususnya untuk anak-anak. Namun, apakah Game tersebut mempunyai nilai produk yang menjanjikan jika dipasarkan melalui 
distributor. Dalam penelitian ini yang dimaksud dengan nilai produk adalah suatu nilai yang dapat dirasakan user dimana didasarkan oleh biaya, nilai pertukaran, estetika, dan fungsi secara relatif (Rizan \& Arrasyid, 2008).

Berdasarkan dari (Rizan \& Arrasyid, 2008), penelitian ini akan mengamati Game Software yang dibuat oleh Mahasiswa Universitas Darma Persada untuk melihat nilai produk yang terkandung dalam Game tersebut. Oleh karena itu, peneliti mengambil nilai produk berdasarkan fungsi secara relatif yang dimana suatu produk yang menghasilkan keuntungan bagi user. Secara lebih luas pengertian nilai produk Game adalah mempunyai nilai jual. Dalam penetapan harga jual produk Game menggunakan pendekatan teori nilai konsumsi. Didalam teori nilai konsumsi yang menunjukan bahwa konsumen memiliki nilai yang berbeda untuk kelompok produk yang nantinya akan menjadi faktor utama motivasi dan perilaku konsumen untuk membeli. Nilai yang dianggap sebagai prediktor kuat untuk memprediksi perilaku pembelian antara lain: nilai fungsional, nilai sosial, nilai emosional. Menurut (Ho \& Wu, 2012) nilai tersebut digunakan sebagai key influencer dalam perilaku konsumen sesuai dengan konteks mereka .Selain itu ada perilaku satisfaction with the game \& identification with the character.yang sangat penting untuk diperhatikan.

Pada penelitian yang dilakukan pada saat ini dibatasi dengan nilai produk yang berdasarkan nilai fungsional dari Game dengan menggunakan metode MAGIQ. Sedangkan fungsionalitas dari metode MAGIQ adalah digunakan untuk pengujian kualitas Software seperti dilakukan oleh (McCaffrey, 2009) atau (Yahlali \& Chouarfia, 2014). Oleh sebab itu, penelitian ini memprioritaskan bagaimana aturan permainan (gameplay) dari Game tersebut dan kinerjanya untuk melihat kualitas dari nilai produk.

\section{B. METODE PENELITIAN}

Dalam penelitian ini peneliti menggunakan metode deskriptif kuantitatif yaitu jenis penelitian yang bertujuan mendeskripsikan secara sistematis faktual dan akurat tentang fakta dan menggambarkan fenomena secara detail dengan pendekatan kuantitatif (Yusuf, 2014). Sedangkan data yang digunakan adalah data primer yaitu data yang diperoleh secara langsung dari sumbernya (pembuat Game) dan data sekunder dengan library research dan field research. Teknik pengumpulan data menggunakan observasi yaitu dengan cara mengamati secara langsung kepada Game tersebut dan menggunakan kuesioner yaitu suatu teknik pengumpulan informasi yang memungkinkan analisis mempelajari sikap,perilaku dan karakter dari Game tersebut melalui orang yang berprofesi sebagai Analisis Sistem, Gamer dan Programmer. Teknik analisa data yang digunakan adalah statistik deskriptif kuantitatif dengan menggunakan metode MAGIQ. Hal tersebut dimaksudkan untuk menguji kualitas nilai produk berdasarkan fungsi yang relatif yaitu antara gameplay dengan kinerja.

Tahap-tahap yang dilakukan pada penelitian ini adalah sebagai berikut :

1. Game Edukasi

Pada penelitian ini, terdapat dua Game Edukasi dari Mahasiswa Darma Persada, antara lain Question Game dan Hit Mice Game. Masing-masing mempunyai kriteria sebagai berikut :

a. Question Game

Tujuan dari game ini adalah memberikan pertanyaan dasar yang dapat dijawab oleh anak Sekolah Dasar, dimana terdapat dua karakter didalam permainan yang masing-masing bertugas member pertanyaan (gambar orang) dan member jawaban (gambar kucing). Setiap pertanyaan yang benar atau salah akan diberi nilai, dan nilai tersebut dimasukkan kedalam papan nilai.Ketika permainan berakhir karakter 
yang memberikan pertanyaan akan mengumumkan jumlah soal yang benar dan yang salah.

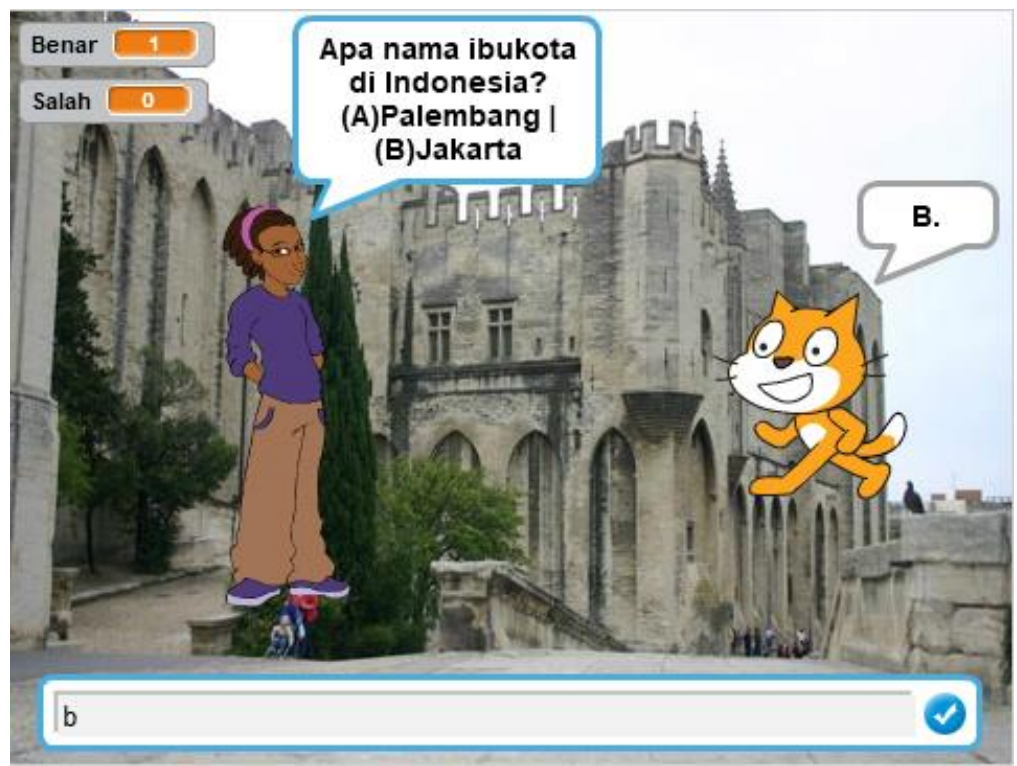

Gambar 1. Permainan Kuis

b. Hit Mice Game

Permainan ini bertujuan untuk menguji ketangkasan anak-anak dalam memukul tikus di dalam lubang. Setiap berhasil memukul satu tikus, maka akan diberikan nilai 10. Kemudian untuk menambah tantangan, diberikan waktu permainan serta permainan diberi Video Game Music (VGM). Pada akhir permainan, jumlah nilai akan diumumkan dan diberi ranking.

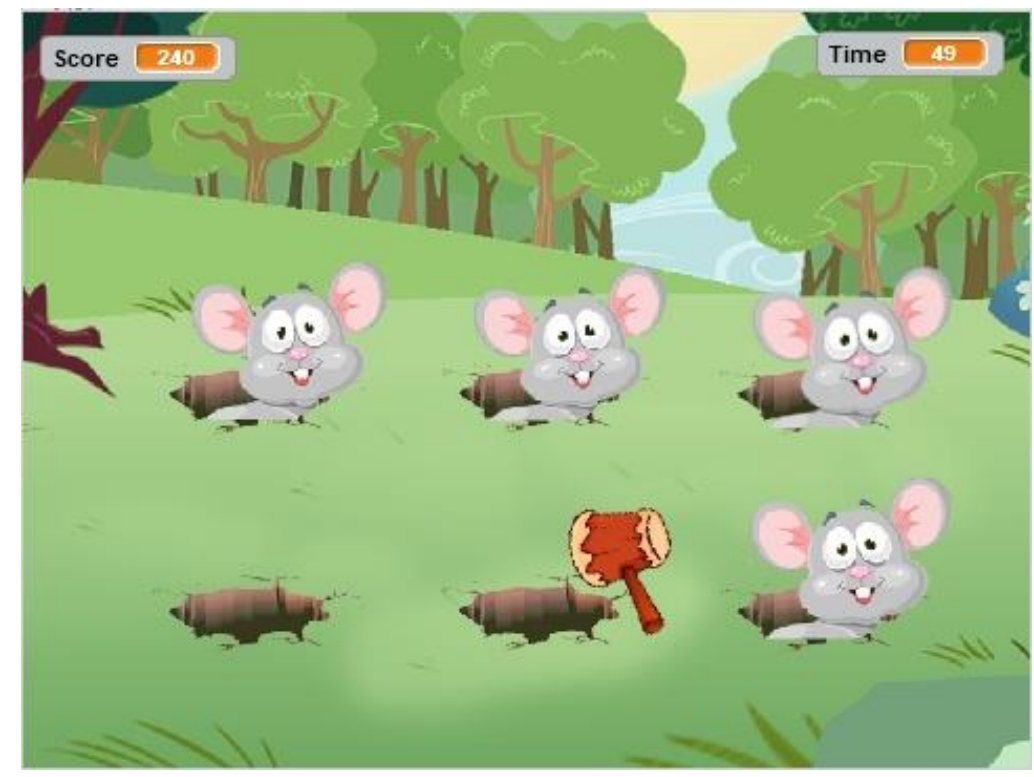

Gambar 2. Permainan Ketangkasan

2. Metode MAGIQ

Multi-Attribute Global Inference of Quality atau disebut dengan MAGIQ diperkenalkan oleh (McCaffrey, 2009) untuk mengukur kualitas software dimana konsepnya diambil dari AHP yang di bawa oleh (Saaty, 2004). Akan tetapi perbedaannya adalah pembobotan menggunakan perankingan dengan membandingkan 
satu kriteria dengan kriteria yang lain yang dimana ditentukan oleh responden sendiri, misalkan jika A lebih tinggi dari $\mathrm{B}$ dan $\mathrm{A}$ lebih tinggi dari $\mathrm{C}$ maka yang menjadi ranking pertama adalah $\mathrm{A}$. Jika $\mathrm{C}$ lebih tinggi dari $\mathrm{B}$, maka ranking kedua adalah $\mathrm{C}$, sehingga kesimpulannya adalah $\mathrm{A}>\mathrm{C}>\mathrm{B}$ (Forte et al., 2018). Hasil ranking yang sudah ditentukan oleh responden tersebut kemudian dihitung dengan ROC (Ranking Order Centroids) dengan rumus (Utami et al., 2016) :

$$
\mathrm{W}_{\mathrm{k}}=\frac{1}{\mathrm{k}} \sum_{\mathrm{i}=1}^{\mathrm{k}}\left(\frac{1}{\mathrm{i}}\right)
$$

Contoh pemakaian rumus adalah jika Ranking 1 dengan jumlah kiteria adalah 3 (misalkan A, B, dan C), maka pengerjaannya $(1+1 / 2+1 / 3) / 3=0,611111$. Kemudian Hasil ROC tersebut disusun berdasarkan matrik secara hierarki seperti contoh Gambar sebagai berikut :

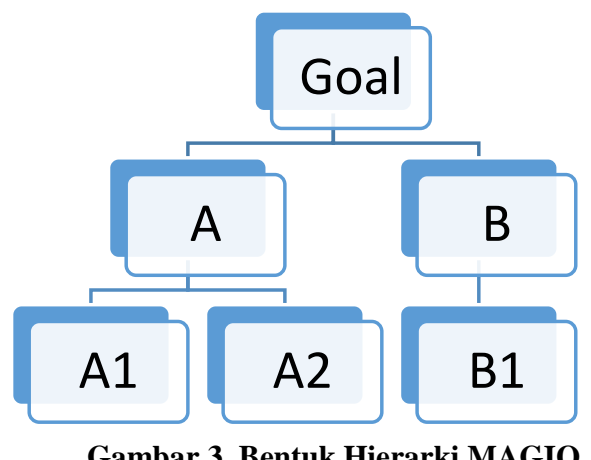

Masing-masing kriteria kemudian dihitung dengan cara $\left(\mathrm{A}^{*} \mathrm{~A} 1\right)+\left(\mathrm{A}^{*} \mathrm{~A} 2\right)+(\mathrm{B} * \mathrm{~B} 1)$, hasil dari perhitungan inilah yang digunakan untuk menentukan keputusan.

\section{HASIL DAN PEMBAHASAN}

Pada metode MAGIQ, game yang dibandingkan berjumlah 2 (dua). Sedangkan untuk menilai produk suatu Game Edukasi yang dipilih oleh 5 (lima) responden yang terdiri dari 2 (dua) orang Analisis Sistem, 2 (dua) orang Gamer dan 1 (satu) Programmer yang ahli pada bidang ini selama lebih dari 5 tahun, Untuk kriteria nilai dari Game Edukasi tersebut disusun oleh responden secara berurutan sebagai berikut :

\section{Gameplay}

a. Menu

b. Konten

c. Level

d. Score

e. Reward
2. Kinerja

a. Kontrol

b. Speedtest

c. Performance

d. Grafik

Namun, ketika melakukan pengamatan pada kedua Game tersebut ternyata tidak terdapat adanya Kriteria Level dan Reward, sehingga nilai ROC yang didapatkan adalah sebagai berikut :

Tabel 1. Nilai (Ranking Order Centroids) ROC

\begin{tabular}{|l|l|}
\hline Nilai Produk & \multicolumn{1}{|c|}{ ROC } \\
\hline Gameplay & 0,75 \\
Menu & 0,611111111 \\
Konten & 0,277777778 \\
Score & 0,11111111 \\
Kinerja & 0,25 \\
Kontrol & 0,520833333 \\
Speedtest & 0,270833333 \\
Performance & 0,145833333 \\
Grafik & 0,0625 \\
\hline
\end{tabular}


Hasil yang didapatkan untuk masing-masing Game Edukasi yang dibandingkan adalah sebagai berikut:

Tabel 2. Hasil Perhitungan MAGIQ

\begin{tabular}{|c|c|c|c|c|c|c|c|c|}
\hline & \multicolumn{3}{|c|}{$\begin{array}{c}\text { Gameplay } \\
0,75\end{array}$} & \multicolumn{4}{|c|}{$\begin{array}{c}\text { Kinerja } \\
0,25\end{array}$} & \\
\hline & Menu & Konten & Score & Kontrol & Speedtest & Performance & Grafik & \\
\hline Jenis Game Edukasi & 0,611 & 0,2778 & 0,111 & 0,5208 & 0,270 & 0,14583 & 0,062 & 1.998 \\
\hline Question Game & 0,25 & 0,25 & 0,25 & 0,75 & 0,25 & 0,25 & 0,25 & 2.75 \\
\hline Hit Mice Game & 0,75 & 0,75 & 0,75 & 0,25 & 0,75 & 0,75 & 0,75 & 4.25 \\
\hline
\end{tabular}

Berdasarkan pengamatan dan penilaian MAGIQ pada kedua Game tersebut, terdapat banyak kekurangan didalamnya. Pertama adalah masalah menu pada Game. Menu Game sangatlah penting yang di bagi menjadi 3 (tiga) kategori utama yaitu Game mulai, Instruksi, dan Keluar. Game mulai berarti user dapat memulai permainan, Instruksi untuk tata cara bermain Game, dan Keluar untuk berhenti bermain serta keluar dari aplikasi. Jika tidak terdapat menu untuk memulai permainan,ini dapat membuat user belum dapat beradaptasi dengan Game tersebut. Karena itu pemasukan Instruksi sangatlah penting, dengan tujuan agar user dapat mempelajari terlebih dahulu tata cara permainan sebelum memulai permainan.

Selanjutnya adalah masalah Konten, suatu permainan dapat dikatakan balance jika sesuai dengan tema dan sesuaikan dengan usia pemain. Misalkan, jika permainan tersebut adalah permainan edukasi sejarah Surabaya, maka sebaiknya isi kontennya adalah cerita sejarah Surabaya dengan dilengkapi teks dan audio. Sertakan juga pertanyaan-pertanyaan sejarah Surabaya agar mendorong user mengingat kembali cerita sejarah pada Gamet ersebut. Jika permainan tersebut adalah Question Game, sebaiknya dibatasi berdasarkan usia. Kemudian, jika ada penambahan karakter pada Game, disesuaikan juga dengan kategori pertanyaannya. Misalkan Pertanyaannya adalah Mata Pelajaran SD, sebaiknya karakternya Guru dan Murid SD. Latar belakang gambar juga sangat penting untuk mendukung tema, misalkan gambar Sekolah SD.

Kinerja pada kedua Game, hampir sama dan sebanding dikarenakan Sumber Daya yang digunakan masih sama. Karena itu, untuk nilai produk dapat dilihat pada tabel sebagai berikut :

Tabel 3. Nilai Produk Game

\begin{tabular}{|c|c|c|}
\hline & Question Game & Hit Mice Game \\
\hline Menu & $\mathrm{X}$ & $\mathrm{V}$ \\
Konten & $\mathrm{X}$ & $\mathrm{V}$ \\
Level & $\mathrm{X}$ & $\mathrm{V}$ \\
Score & $\mathrm{V}$ & $\mathrm{X}$ \\
Reward & $\mathrm{X}$ & $\mathrm{V}$ \\
Kontrol & $\mathrm{V}$ & $\mathrm{V}$ \\
Speedtest & $\mathrm{V}$ & $\mathrm{V}$ \\
Performance & $\mathrm{V}$ & $\mathrm{V}$ \\
Grafik & $\mathrm{V}$ & \\
\hline
\end{tabular}

Berdasarkan pada tabel di atas dapat disimpulkan bahwa kemungkinan Game yang dominan mempunyai nilai produk adalah Hit Mice Game. Namun, ada kriteria penting yang belum dimasukan pada Game tersebut yaitu Level dan Reward. Kedua kriteria ini sangatlah penting dikarenakan sebagai pengukuran berapa lama user akan betah mampu berlama-lama bermain. Sedangkan level menyatakan sebagai tingkat kesulitan permainan dan Reward adalah hasil kerja keras user untuk mencapai target. Karena itu, perlu dilakukan pengujian alpha (pengujian tools, algoritma dan sebagainya) untuk 
menverifikasi produk dalam pengembangan Game sebelum diumumkan ke publik khususnya pemain Game.

Hasil perhitungan dengan metode MAGIQ tersebut diatas dilakukan untuk menguji nilai produk Game Edukasi yang berkualitas yang selanjutnya dapat memberikan dampak positif yaitu tumbuh suburnya Industri kreatif dari Game, yang akhirnya akan berpengaruh pada perekonomian bangsa. Disamping itu merupakan tantangan bagi pembuat Game lokal untuk bersaing dengan pembuat Game dari Luar Negeri.

Menurut (Fajri, 2012), hambatan yang dialami oleh pembuat Game Lokal antara lain kurangnya perhatian dan dukungan pemerintah misalkan berupa peraturan,perlindungan hak cipta, belum banyaknya institusi pendidikan yang secara spesifik memberikan pendidikan tentang bagaimana membuat serta memasarkan sebuah Game, masyarakat Indonesia belum bisa mengapresiasi suatu karya dengan baik. Hal tersebut perlu kerjasama antara pemerintah,masyarakat dan pengembang Game untuk mempertahankan kualitas produknya.

Selanjutnya di dalam pengujian alpha, kualitas produk Game perlu dilakukan juga dengan meninjau dari standar kualitas ISO 9126. Berdasarkan dari (P. et al., 2014), penelitiannya menghasilkan aspek utama yang berpengaruh terhadap kualitas produk adalah faktor yang memiliki nilai signifikansi yang lebih besar yaitu meliputi aspek functionality, usability dan portability. Diharapkan para pengembang memiliki acuan untuk menilai perangkat lunak Game yang telah dibuat dilihat dari ISO 9126.

\section{SIMPULAN DAN SARAN}

Berdasarkan hasil dari perhitungan pendekatan metode MAGIQ, bahwa nilai produk Mahasiswa Universitas Darma Persada yang dominan pada Hit Mice Game, dimana kriterianya hampir semua dipenuhi jika dibandingkan dengan Question Game. Akan tetapi, Kriteria Level dan Reward tidak terdapat di dalam Game tersebut. Kedua kriteria ini sangatlah penting dikarenakan sebagai pengukuran berapa lama user akan betah mampu berlama-lama bermain. Level menyatakan sebagai tingkat kesulitan permainan dan Reward adalah hasil kerja keras user untuk mencapai target. Oleh sebab itu, perlu dilakukan test alpha untuk menverifikasi produk dalam pengembangan Game.

Untuk rencana jangka panjang disarankan penelitian Game seharusnya dilanjutkan dengan pendekatan teori nilai konsumsi yang menghasilkan nilai jual suatu produk. Hal tersebut akan memberikan motivasi dan semangat serta mendorong inovasi, kreatifitas kepada pembuat Game di Indonesia untuk terus menerus berkarya. Selanjutnya diharapkan Game yang merupakan salah satu sektor ekonomi kreatif dapat ikut berperan menyumbangkan pendapatan untuk Produk Domistik Bruto di Indonesia.

\section{DAFTAR PUSTAKA}

Fajri, C. (2012). Tantangan Industri Kreatif- Game Online di Indonesia. Jurnal Komunikasi, 1(5), 443-454.

Fithri, D. L., \& Setiawan, D. A. (2017). ANALISA DAN PERANCANGAN GAME EDUKASI SEBAGAI MOTIVASI BELAJAR UNTUK ANAK USIA DINI. Simetris, 8(1), 225-230.

Forte, S. A. B., Forte, S. H. A. C., \& Pinheiro, P. R. (2018). Strategic Decision Method Structured in SWOT Analysis and Postures Based in the MAGIQ Multicriteria Analysis. Advances in Intelligent Systems and Computing, 662, 227-237. https://doi.org/10.1007/978-3-319-67621-0_21

Ho, C.-H., \& Wu, T.-Y. (2012). FACTORS AFFECTING INTENT TO PURCHASE VIRTUAL GOODS IN ONLINE GAMES. International Journal of Electronic 
Business Management (Vol. 10). Diperoleh dari dari https://pdfs.semanticscholar.org/5329/3bb57dd6ce1ae386469912d771e8f902dfba.pdf

McCaffrey, J. D. (2009). Using the Multi-Attribute Global Inference of Quality (MAGIQ) technique for software testing. In ITNG 2009 - 6th International Conference on Information Technology: New Generations (h. 738-742). https://doi.org/10.1109/ITNG.2009.81

P., G. D., M., R. F. I., \& Rochimah, S. (2014). Pengukuran Kualitas untuk Aplikasi Permainan pada Perangkat Bergerak berdasarkan ISO 9126. ULTIMA InfoSys, 5(2), 83-90. https://doi.org/https://doi.org/10.31937/si.v5i2.269

Rizan, M., \& Arrasyid, H. (2008). Analisis Asosiasi Merek, Nilai Produk, dan Kualitas Pelayanan Serta Pengaruhnya Terhadap Kepuasan dan Loyalits Konsumen Sepeda Motor di Bekasi. Jurnal Siasat Bisnis, 12(2), 129-147.

Saaty, T. L. (2004). Decision making — the Analytic Hierarchy and Network Processes (AHP/ANP). Journal of Systems Science and Systems Engineering, 13(1), 1-35. https://doi.org/10.1007/s11518-006-0151-5

Utami, R. T., Andreswari, D., \& Setiawan, Y. (2016). IMPLEMENTASI METODE SIMPLE ADDITIVE WEIGHTING ( SAW ) DENGAN PEMBOBOTAN RANK ORDER CENTROID ( ROC ) DALAM PENGAMBILAN KEPUTUSAN UNTUK SELEKSI PENGGUNA JASA LEASING MOBIL ( Studi Kasus : PT . Multindo Auto Finance Cabang Bengkulu ). Rekursif, 4(2), 209-221.

Yahlali, M., \& Chouarfia, A. (2014). SCAE: Software component assembly evaluation. International Journal of Software Engineering and its Applications, 8(3), 255-268. https://doi.org/10.14257/ijseia.2014.8.3.24

Yusuf, A. M. (2014). Metode Penelitian Kuantitatif, Kualitatif \&amp; Penelitian Gabungan. Jakarta: Penerbit Prenadamedia Group . Diperoleh dari dari https://books.google.co.id/books/about/Metode_Penelitian_Kuantitatif_Kualitatif.ht ml?id=RnA-

DwAAQBAJ\&printsec $=$ frontcover\&source=kp_read_button\&redir_esc $=\mathrm{y} \# \mathrm{v}=$ onepag $\mathrm{e} \& \mathrm{q} \& \mathrm{f}=\mathrm{false}$ 